\title{
The Students' Talk on Politeness and Impoliteness Interaction in Classroom
}

\author{
Andi Suwarni ${ }^{1 *}$ Aulia Bestari² \\ 1,2, Universitas Muhammadiyah Bone, Watampone, Indonesia \\ *Corresponding author. Email: andisuwarni305@gmail.com
}

\begin{abstract}
The purpose of this study was to examine how students used politeness and impoliteness in their classroom interactions. The study looks into the different sorts of politeness and impoliteness talk those students employ in class. This study was a descriptive qualitative study. The students in the English Education Department at STKIP Muhammadiyah Bone in the fourth semester were the focus of this study. The researcher used an observation checklist as well as audio recordings. Researchers did a few steps to investigate the records, specifically; records reduction, statistics display, and conclusion drawing and verification. The researcher used Brown and Levinson (1987)'s politeness concept particularly; bald-on record, positive politeness, negative politeness, and stale-document and Culpeper (1996)'s impoliteness principle, specifically; bald on the report, positive impoliteness, negative impoliteness, sarcasm or mock politeness, and withhold politeness. The resulting finding of this research indicated there were three types of politeness talk used by the students in classroom interaction. They were bald on record, positive politeness, and negative politeness. From 149 of students' utterances, 2 of them identified as bald on record, 139 as positive politeness, and 6 as negative politeness. Positive politeness dominated the use of politeness talk by the students in classroom interaction. Meanwhile, there were three types of impoliteness talk used by the students in classroom interaction. They were bald on record, positive impoliteness, and negative impoliteness. From 11 of students' utterances, 4 as bald on record, 6 of them identified as positive impoliteness, and 1 as impoliteness in negative. Positive impoliteness dominated the use of impoliteness talk by the students in classroom interaction. From 3 groups divided in the classroom, the first group used the most politeness talk which was 61 utterances. Meanwhile, the group which used the most impoliteness talk was the third group that uttered 5 utterances.
\end{abstract}

Keywords: politeness, impoliteness, interaction in the classroom

\section{INTRODUCTION}

The important thing used to communicate in daily life is language. Communication is a process of delivering a message from one person to another that aims to inform, express opinions, and change attitudes behaviours performed either directly or indirectly. Everyone has different language styles in communicating because the most important thing in communicating is to transfer what a person thinks, feels, or experiences to make others understand. One way to establish good communication is by applying politeness. Politeness is one of the most important issues, especially in Indonesia. Indonesia is known for its hospitality and courtesy in the eyes of the world. Characteristics of Indonesian society as a people who uphold the value of brotherhood, mutual respect and appreciation are very thick. On the education side itself, politeness is often shown by teachers and students through speech or attitude, such as speaking softly and smiling when speaking.

Politeness is a regularly occurring and exceptional expressed as the practical application of excellent manners or etiquette. The avoidance is represented as an aware effort on the section of the man or woman to be polite. Politeness techniques are more in all likelihood to be used when a speaker of incredibly decrease energy makes a large request in a greater distant relationship than when a speaker of exceedingly greater electricity makes a smaller request in a closer relationship (Brown \& Levinson, 1987). Brown and Levinson (1987:65) argue that an FTA (Face Threatening Act) frequently requires a mitigating assertion or some type of politeness, or the line of verbal exchange will break. Therefore, four probabilities of politeness strategies are 
wished to minimize FTA. The techniques are bald on record, tremendous politeness, and terrible politeness. The other one set is "off record" strategy. There is some symbol that is used in this theory, namely: FTA for Face threatening Act, $\mathrm{S}$ for Speaker, and $\mathrm{H}$ for Hearer.

The idea of politeness and impoliteness has been one of the controversial issues and has been defined in many special methods on account that politeness theory used to be first brought by Brown and Levinson. Brown and Levinson's theory, which is based on Goffman's face thinking and Grice's maxims, states that any conduct that tries to protect the face of the addressee is polite; therefore, any behaviour that assaults the face of the addressee is impolite. Most of the definitions of impoliteness centre on the face notion.

The social norms role is some other dimension; Holmes et al. emphasize the significance of social norms and the understanding of the hearer whilst ignoring the role of intentionality. They define verbal impoliteness as “... linguistic conduct assessed by way of the hearer as threatening her or his face or social identity and infringing the norms of fabulous conduct that be triumphant in specific contexts and amongst unique interlocutors, whether or not intentionally or not"(2008:196 noted in Aydınoğlu, N, 2013). Culpeper's 2005 definition covers each intentionality and hearer's perception: "Impoliteness comes about when: (1) the speaker communicates face- assault intentionally, or (2) the hearer perceives and/or constructs behaviour as deliberately face-attacking, or a mixture of (1) and (2) (2005:38 cited in Aydınoğlu, N, 2013). There are contrary in phrases of orientation to face. Instead of enhancing or aiding face, impoliteness splendid strategies are a means of attacking face.

Interaction takes an essential function in instructing the mastering process. Interaction's manner is constantly carried out by the teacher and the students in the classroom. It occurs even it is for teachers to students, students and teacher, and students to students, they have to be polite to engage each other. It will guide the fine situation of teaching and getting to know activity. When the educating and mastering in the lecture room run effective, there will be a harmonious condition that will make the procedure of enquiring new knowledge run well.

In classroom interaction, language is spoken naturally by students. Students are free to talk, answer, and explain as they are with their language. They used to talk in their way. Often the language used is not as polite as their teachers. The teacher has explained the material using polite language during class discussions. But students use natural language that they use in their daily interactions sometimes they become impolite with their friends even during the process of giving explanations, asking questions, answering, or debating. The interaction between students was established well. Students often speak freely according to their style but are often incompatible with situations and conditions especially when in the classroom. Most students speak informally and tend to be impolite to fellow friends. In this study, the researcher analysed utterance or talk used by the students in terms of politeness and impoliteness in classroom interaction.

\section{METHOD}

In this research, the researcher utilized the descriptive qualitative method. The method of descriptive qualitative produces descriptive information in the form of phrases of people that can be found to analyze the politeness and impoliteness speak used by way of the college students in classroom interaction. The research subject was the students English Education Department at the fourth semester of STKIP Muhammadiyah Bone.

The instrument was the observation checklist which is politeness observation checklist and impoliteness observation checklist. The politeness observation checklist consisted of 4 items. The first item was bald on record which had 2 sub items; the second item was positive politeness which had 15 sub-items. The third item was negative politeness which had 10 sub-items. The fourth item was off the record which had 15 subitems. The impoliteness observation checklist consisted of 5 sub-items. This research use non-participant observation where the researcher will not participate and engage with the subject. In the collection of the data in this research, the researcher did observation during the process of learning and teaching in the classroom.

First, the evaluation of the record of records discounts the manner of selecting, focusing, simplifying, abstracting, and reworking the statistics that appear in written-up subject notes or transcriptions. They in addition factor out that the records reduction or statistics condensation method is diverse in various ways, such as via selection, precis or paraphrase and being subsumed in the larger pattern. After gathering the information of students' utterances and conversations, the researcher continued the lookup through choosing and simplifying the data of the students' utterances and dialogue which comprise politeness and impoliteness talk so that there used to be no unimportant utterance encompassed in the data.

The next point of facts evaluation is facts display. After gathering and decreasing the data, the researcher displayed the amassed records in equipped and compressed records that led to the conclusion. The researcher categorized the statistics of the students' politeness and impoliteness talk. After exhibiting the data, then the researcher was capable to interpret it and attain conclusions and verifications. The subsequent step that was once be performed via the researcher was describing and interpreting the statistics so that the conclusions and verifications of the politeness and impoliteness speak utilized utilizing the students can be drawn. 


\section{ANALYSIS}

The finding here about politeness and impoliteness talk used by the students in classroom interaction that found by the researcher. The politeness talk consists of three types; they are bald on record that consists of 1 extract of cases of non-minimization of the face threat. Negative politeness consists of 4 extracts; 1 extract of being pessimistic, 1 extract of minimizing the imposition, 1 extract of Apologize, and 1 extract of Impersonalize speaker and hearer. The impoliteness talk consists of three types; they are bald on record that consists of 1 extract, positive impoliteness that consists of 5 extracts, and negative impoliteness that consists of 1 extract. It can be shown as below:

1. The politeness talk in classroom interaction

a. Bald on Record

Bald on the report is typically used when an individual needs to do the face-threatening act with maximum effectivity greater than he wants to satisfy the hearer's face. The researcher analyzed the kind of bald on the document used with the aid of the students; this was once a case of non-minimization of the face threat. The extract beneath suggests how this type of bald on file is used in study room interaction.

Table 1. The Frequency of Bald on Record Politeness Talk Usage

\section{Frequency}

\begin{tabular}{cc}
\cline { 2 - 3 } Item Sub item & $\begin{array}{c}\text { First Second Third } \\
\text { group group group }\end{array}$
\end{tabular}

\begin{tabular}{lllll}
\hline $\begin{array}{l}\text { Bald on Cases of } \\
\text { Record }\end{array}$ & & & & 2 \\
$\begin{array}{c}\text { mon- } \\
\text { minimizati } \\
\text { on of the } \\
\text { facethreat }\end{array}$ & 1 & 1 & - & \\
\hline Total & 1 & 1 & - & 2 \\
\hline
\end{tabular}

\section{b. Positive in Politeness}

The positive politeness method suggests that your hearer has a desire to be revered (Brown and Levinson, 1987). Its skill that hearer ought to possibly have precise friendship with the speaker, which both has a have the confidence to make quality time in conversation. Positive politeness is the strategy that minimizes social distance.
Table 2. The Frequency of Positive Politeness Talk Usage

\section{Frequency}

Item Sub items First Second Third Total
group group group

\begin{tabular}{llllll}
\hline Positiv & 1 Notice, & - & - & 2 & 2 \\
e & attend to & & & & \\
Politen & Hearer & & & & \\
ess & (his & & & & \\
& interest, & & & & \\
& wants, \\
& needs, & & & \\
& goods) & & & \\
\end{tabular}

\begin{tabular}{|c|c|c|c|c|}
\hline $\begin{array}{l}\text { 2) } \\
\text { Exaggerat } \\
\text { e (interest, } \\
\text { approval, } \\
\text { sympathy } \\
\text { with } \\
\text { Hearer) }\end{array}$ & - & - & 1 & 1 \\
\hline $\begin{array}{l}\text { 3) } \\
\text { Intensify } \\
\text { interest to } \\
\text { Hearer }\end{array}$ & 37 & 27 & 21 & 85 \\
\hline $\begin{array}{l}\text { 4) Use in- } \\
\text { group } \\
\text { identity } \\
\text { markers }\end{array}$ & 1 & 1 & 5 & 7 \\
\hline $\begin{array}{l}5) \quad \text { Seek } \\
\text { agreement }\end{array}$ & 13 & 2 & 8 & 23 \\
\hline 6) Joke & 8 & 5 & 4 & 17 \\
\hline $\begin{array}{l}\text { 7) } \quad \mathrm{Be} \\
\text { optimistic }\end{array}$ & - & - & 1 & 1 \\
\hline $\begin{array}{l}\text { 8) Include } \\
\text { both } S \text { and } \\
\mathrm{H} \text { in the } \\
\text { activity }\end{array}$ & 1 & 2 & 1 & 4 \\
\hline $\begin{array}{l}\text { 9) Give } \\
\text { gifts to H } \\
\text { (goods, } \\
\text { sympathy, }\end{array}$ & - & 1 & - & 1 \\
\hline
\end{tabular}




\section{understand}

ing,

cooperatio

n)

$\begin{array}{lllll}\text { Total } & 59 & 38 & 43 & 140\end{array}$

\section{c. Negative in Politeness}

Negative politeness is oriented to fulfil H's bad face, his fundamental wishes to be free and unimpeded. It can be understood that a negative Face is a want no longer to be imposed upon or disturbed. The researcher analyzed the kind of effective politeness used by using the pessimistic students, reducing the imposition, apologizing, and impersonalizing speaker and hearer. The extracts under exhibit how this type of politeness is used with the aid of the college students in study room interaction:

2. The impoliteness talk utilized in classroom interaction by the students

From the data, the researcher found some impoliteness talk utilized in classroom interaction by the students. Those impoliteness talks were bald on record, impoliteness in positive, and impoliteness in negative.

Table 3. The Frequency of Impoliteness Talk Usage

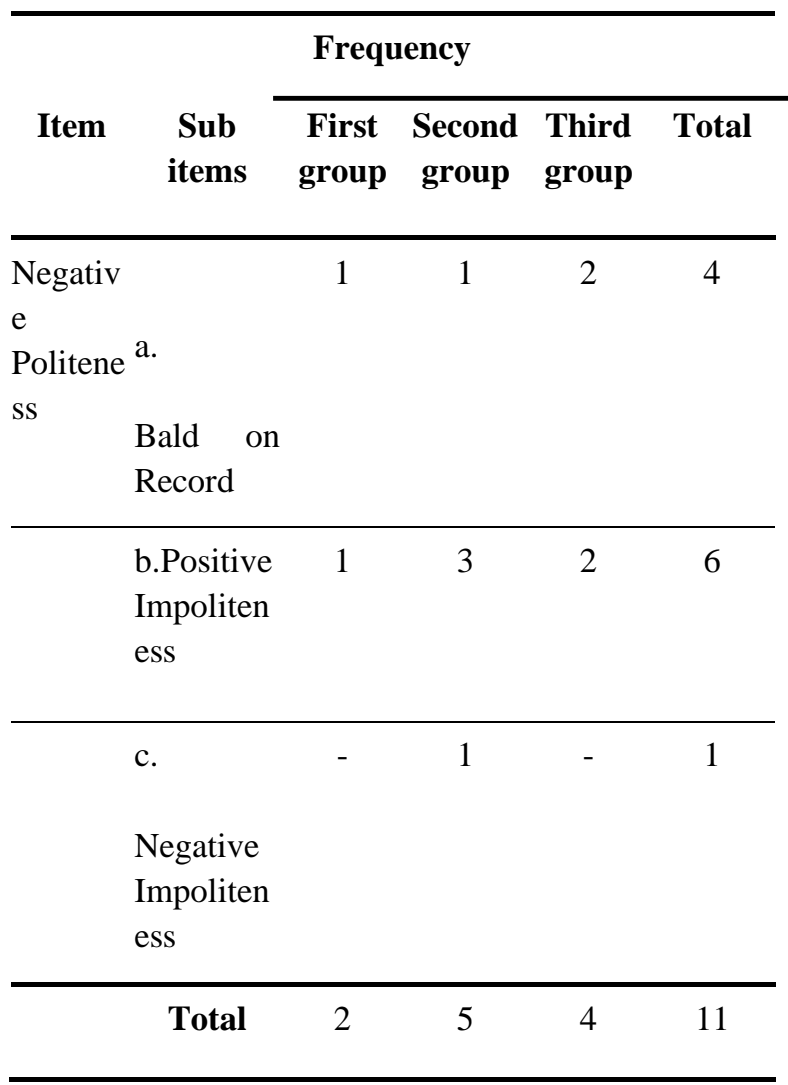

\section{CONCLUSION}

Based on the research findings above, it may be concluded that in classroom interaction with the English education department student of STKIP Muhammadiyah Bone, the students used three sorts of politeness talk. They are bald on record, positive politeness, and negative politeness. The data finding indicates that from the total range of 149 utterances, 2 utterances used bald on the report, the kinds have been cases of nonminimization of the face threat, 139 utterances used positive politeness, the kinds had been noticed, attend to the hearer (his interest, desires, wishes, goods), exaggerate (interest, approval, sympathy with hearer), intensify hobby to the hearer, use in-group identification markers, are looking for agreement, joke, be positive, encompass each $\mathrm{S}$ and $\mathrm{H}$ in the hobby, and give presents to $\mathrm{H}$ (goods, sympathy, information, cooperation). 6 utterances used terrible politeness, the sorts had been pessimistic, limit the imposition, make an apology, and impersonalize speaker and hearer.

The usage of politeness communicates became ruled through positive politeness which turned into utilized in 139 utterances. Positive politeness is the method that minimizes social distance. it also includes seen in friend groups, or wherein humans inside the given social scenario understand each other fairly well. It tries to limit the distance among them by using expressing friendliness and solid interest in the hearer's need (Brown Levinson, 1987). From 3 groups divided within the study room, the primary institution used maximum politeness talk which become 61 utterances.

Students used three sorts of impoliteness talk. They are bald on record, impoliteness in positive, and impoliteness in negative. The data found that from the total number of 11 utterances, 4 utterances used bald on record, 6 utterances used positive impoliteness, and 1 utterance used negative impoliteness. The use of impoliteness discussion was dominated utilizing positive impoliteness which was used in 6 utterances. From 3 groups divided in the classroom, the group which used the most impoliteness discuss was once the third group that uttered 5 utterances.

\section{AUTHORS' CONTRIBUTIONS}

A.S. and A.B. conceived of the offered idea. A.B. developed the concept and accomplished the computations. A.S. proven the analytical techniques. A.S. recommended A.B. to research the precise thing and supervised the findings of this paintings. All authors mentioned the consequences and contributed to the very last manuscript.

A.S., and A.B. contributed to the layout and implementation of the research, to the evaluation of the effects and to the writing of the manuscript. 


\section{ACKNOWLEDGMENT}

The paper and the lookup at the back of it would not have been viable barring assist of all. I acknowledge this contribution of my partner, Aulia Bestari, who has given up to review this paper and the responses it has generated. Thank her who helped with this research.

\section{REFERENCES}

[1] Allwright, D. and Bailey, K. M. (1991). Focus on the Language Classroom: An Introduction to Classroom Research for Language Teachers. United Kingdom: Cambridge University Press.

[2] Aydınoğlu, N. (2013). Politeness and Impoliteness Strategies: An Analysis of Gender Differences in Geralyn 1. Horton's Plays. Article of Procedia - Social and Behavioral Sciences https://www.researchgate.net/publication/ Accessed on March 8, 2019.

[3] Brown, Penelope and Levinson, Stephen. (1987). Politeness: Some Universals in Language Usage, Studies in Interactional Sociolinguistics. Cambridge University Press.

[4] Culpeper, J. (1996). Towards An Anatomy of Impoliteness. Journal of Pragmatics https://www.researchgate.net/publication/2224979 $\underline{02}$ Accessed on March 8th, 2019.

[5] Harmer, Jeremy. (2001). The Practice of English Language Teaching, 3rd Ed. New York: Pearson Education Limited.

[6] Mahmud, Murni. (2010). Politeness in Bugis: A Study in Linguistic Anthropology. Makassar: Badan Penerbit Universitas Negeri Makassar.

[7] Mahmud, Murni. (2011). Rituals of Politeness in Bugis Society. Journal of FBS The State University of Makassar. http://www.bing.com/search Accessed on March 2nd, 2019.

[8] Nailah. (2016). Politeness Strategies Used by the Main Characters in "Transformer: Age of Extinction" movie. A Thesis of Maulana Malik Ibrahim State Islamic University of Malang.

[9] Scrivener, Jim. (2005). Learning Teaching: A Guidebook for English Language Teachers. MacMillan Book.

[10] Senowarsito. (2013). Politeness Strategies in Teacher-Student Interaction in an EFL Classroom Context. Journal of IKIP PGRI Semarang. http://www.bing.com/searchsenowarsito Accessed on March 2nd, 2019.
[11] Watts, R. J. (2003). Politeness. United Kingdom: Cambridge University Press.

[12] Wibowo, G.P. and Kuntjara, K. (2012). Impoliteness Strategies Used on Online Comments in An Indonesian Football Website. Journal of English Department Petra Christian University. https://core.ac.uk/download/pdf/11852199.pdf. Accessed on March 2nd, 2019. 